\title{
Bilateral central retinal vein occlusion in a neonate secondary to atrial septal defect and patent ductus arteriosus
}

\author{
Akash Belenje, Komal Agarwal
}

Srimati Kannuri Santhamma Center for Vitreo-retinal diseases, L V Prasad Eye Institute, Hyderabad, India

\section{Correspondence to} Dr Komal Agarwal; komal.agarwal.vr@gmail.com

Accepted 13 January 2022

\section{DESCRIPTION}

A 15-day-old late preterm male baby was admitted in the neonatal intensive care unit (NICU). He was delivered at 36 weeks of gestation by normal vaginal delivery and weighed $980 \mathrm{~g}$ at birth. He was admitted in the NICU due to severe intrauterine growth restriction (IUGR) and had multiple comorbidities like very low birth weight, birth asphyxia, respiratory distress syndrome, atrial septal defect (ASD) with patent ductus arteriosus (PDA), abdominal distension due to ascites and thrombocytopenia (78 000/ $\mathrm{mm}^{3}$ ). Ophthalmic examination was requested as a part of the protocol for IUGR evaluation. The anterior segment evaluation of both eyes was unremarkable with well-dilating pupils to topical mydriatic (tropicamide $1 \%$ and phenylephrine $2.5 \%$ ). Lens was clear in both eyes. Fundus examination revealed the presence of dilated and tortuous veins in both eyes with extensive intraretinal flame-shaped and dot haemorrhages at the posterior pole and in all the four quadrants (figure 1). The foveal reflex was dull and the contour seemed elevated on indirect ophthalmoscopy. A diagnosis of central retinal vein occlusion (CRVO) with macular oedema in both eyes was made. Both eyes underwent intravitreal bevacizumab one-third dose of adult dose $(0.4 \mathrm{mg} / 0.015 \mathrm{~mL})$ under aseptic condition in the presence of a neonatologist in the NICU. At postinjection day 3, the haemorrhages and venous tortuosity were on reducing course and a favourable response was noted. However, the baby succumbed to the comorbidities a week

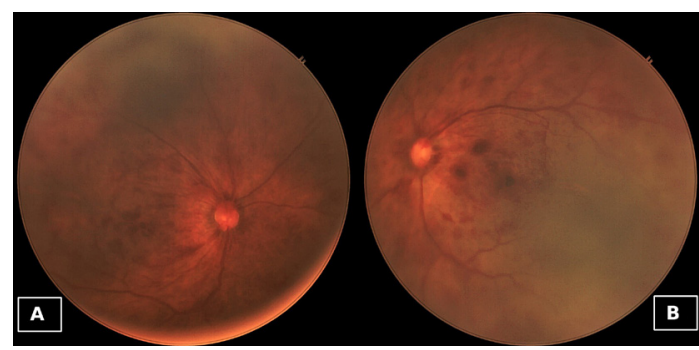

Figure 1 (A) Right eye and (B) left eye: both eyes dilated. Fundus examination showed dilated and tortuous veins with multiple flame-shaped haemorrhages at the posterior pole and also in all the four quadrants, suggestive of central retinal vein occlusion with macular oedema. later due to which the subsequent follow-up was not possible.

Infants with congenital heart diseases (CHDs) like septal defects, PDA, pulmonary stenosis, coarctation of aorta, transposition of great vessels and cyanotic heart diseases are at a higher risk of developing retinal vascular occlusion and retinal haemorrhages. ${ }^{1-3}$ These CHDs can cause volume overload with alteration in hematocrit values, hypoxia due to the admixing of arteriovenous blood and also cardiovascular stress due to the obstruction imposed on the blood flow. ${ }^{1-5}$ In fetal circulation, ductus arteriosus is an essential communication between pulmonary artery and aorta, which closes spontaneously within 48 hours of birth. ${ }^{45}$ In full-term babies soon after birth, the rise in arterial oxygen tension and reduction in circulating prostaglandins results in the constriction of the ductus arteriosus. ${ }^{45}$ Failure of closure of ductus arteriosus is more common in preterm newborns, and this results in volume overload on the pulmonary blood flow. ${ }^{45}$ CRVO in newborns has been previously reported due to thromboembolic episodes due to deranged haematological parameters like protein $\mathrm{C}$ deficiency and hyperhomocysteinemia, postlaser photocoagulation for retinopathy of prematurity, CHDs and intracerebral haemorrhage. ${ }^{16-9}$ In our case, we could not evaluate other haematological parameters before the death of the baby although thrombocytopenia was present. We believe the severe volume overload attributed to the ASD and PDA is the primary cause for bilateral CRVO. To the best of our knowledge, there is no case report on bilateral CRVO secondary to ASD and PDA in newborns. This report sends a message regarding the importance of fundus examination in newborns with CHD irrespective of gestational age of delivery.

\section{Learning points}

Newborns with congenital heart disease (CHD) like atrial septal defect and patent ductus arteriosus are at a risk of developing central retinal vein occlusion.

- Fundus examination in newborns with CHD is important irrespective of their gestational age at delivery. 
Contributors Both $\mathrm{AB}$ and $\mathrm{KA}$ have significant contributions in patient management, data collection, manuscript writing and final editing

Funding The authors have not declared a specific grant for this research from any funding agency in the public, commercial or not-for-profit sectors.

Competing interests None declared.

Patient consent for publication Consent obtained from parent(s)/guardian(s).

Provenance and peer review Not commissioned; externally peer reviewed.

Case reports provide a valuable learning resource for the scientific community and can indicate areas of interest for future research. They should not be used in isolation to guide treatment choices or public health policy.

\section{REFERENCES}

1 Mansour AM, Bitar FF, Traboulsi El, et al. Ocular pathology in congenital heart disease. Eye 2005;19:29-34.
2 Goldmuntz E. The epidemiology and genetics of congenital heart disease. Clin Perinatol 2001;28:1-10.

3 Lewin MB. The genetic basis of congenital heart disease. Pediatr Ann 2000;29:469-80.

4 Hermes-DeSantis ER, Clyman RI. Patent ductus arteriosus: pathophysiology and management. J Perinatol 2006;26 Suppl 1:S14-18.

5 Clyman RI. Ibuprofen and patent ductus arteriosus. N Engl J Med 2000;343:728-30.

6 Phalak D, Rani PK, Balakrishnan D, et al. Central retinal vein obstruction in a neonate occurring during laser photocoagulation treatment for retinopathy of prematurity. J Pediatr Ophthalmol Strabismus 2014;51 Online:e72-4.

7 Parappil H, Oklah M, Al Rifai H, et al. Congenital protein C deficiency with renal vein thrombosis and central retinal venous occlusion in a term neonate due to novel mutation in the proC gene. J Clin Neonatol 2017;6:116.

8 Chen C-Y, Tsao P-N, Young C, et al. Bilateral central retinal vein occlusion with multiple intracerebral hemorrhage in a neonate. Pediatr Neurol 2003;28:400-2.

9 Karth P, Singh R, Kim J, et al. Bilateral central retinal artery occlusions in an infant with hyperhomocysteinemia. J Aapos 2012;16:398-400.

Copyright 2022 BMJ Publishing Group. All rights reserved. For permission to reuse any of this content visit

https://www.bmj.com/company/products-services/rights-and-licensing/permissions/

BMJ Case Report Fellows may re-use this article for personal use and teaching without any further permission.

Become a Fellow of BMJ Case Reports today and you can:

- Submit as many cases as you like

- Enjoy fast sympathetic peer review and rapid publication of accepted articles

- Access all the published articles

- Re-use any of the published material for personal use and teaching without further permission

\section{Customer Service}

If you have any further queries about your subscription, please contact our customer services team on +44 (0) 2071111105 or via email at support@bmj.com.

Visit casereports.bmj.com for more articles like this and to become a Fellow 